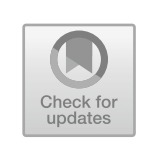

\title{
Impurity and Danger: \\ Excerpt from Cape Calypso
}

\section{Oscar Hemer}

You can get lost in Stellenbosch. The first day at the Institute, ze walks out in the wrong direction, following Marais street instead of van Riebeck, and when ze realises the mistake and tries to correct it, without either a map or the direction of hir residence, ze soon gets disoriented in the lofty labyrinth of shaded pave walks and white rectangular buildings, departments, dormitories, all belonging to the University; like a city plan by Le Corbusier, sanitary, modern, conspicuously white, buzzing with students who have just returned from the summer break, Afrikaans-speaking, conspicuously white with scattered exceptions in pairs or small groups, their faces shades of brown, not black, bruin-mense, as they were benevolently branded by their white superiors. Ze is going to walk these streets every day in the coming months, but this first impression of disorientation will persist in a latent feeling of estrangement. Where is ze? It could be a campus town anywhere in the affluent West, California, Australia, a subtropical Holland-Hottentot Holland - a garden city with vineyards climbing the

\footnotetext{
O. Hemer $(\bowtie)$

Faculty of Culture and Society, School of Arts and Communication, Malmö

University, Malmö, Sweden

e-mail: oscar.hemer@mau.se

(C) The Author(s) 2020

O. Hemer et al. (eds.), Conviviality at the Crossroads, https://doi.org/10.1007/978-3-030-28979-9_13
} 
backdrop of the majestic mountains. This is the cradle of apartheid. It's hard to believe, unless you think of it as benevolent evil. D. F. Malan, the first prime minister of the apartheid state was chancellor of Stellenbosch University when his National Party ascended to power in 1948. His hat and pipe, a rock-hanger and a few bookshelves are left as curious props in a corner of the University museum, between the ethnographic display of tribal cultures and the dull mimicry of modern art. Dr. Hendrik Verwoerd, the engineer rather than the architect, the brutal implementer of the master plan, had been Professor of Sociology at this same university in the formative 1930s, but his imprint is somehow retouched from the records. His as staunch successor, John Vorster, was a former Law student at Stellenbosch, and Verwoerd's closest collaborator in the Ministry for Native Affairs, Werner Eiselen, had held the chair as Professor in Volkekunde, the science of physical and cultural anthropology that formed the academic basis for the ideology of apartness and separate development. Eiselen, the benevolent racist, loyal bureaucrat and perverse visionary, proposing total separation as the only way in which African cultures could be protected from the pernicious effects of urbanisation (Kross 2002: 60). Ze looks for vestiges of oppression, of surveillance, the fencing off of the barbarians at the gate, but dividing lines are invisible or internalised, not blurred; the campus security policing the streets is so discrete that one could take them for road workers in their orange vests. While xenophobia rampages the country, Stellenbosch remains a bubble, even when load shedding blacks out the streets, the whites confidently torch their way back to their moderately armoured residencies.

A discretely grey hardcover copy of the third impression (from 1970) is delivered with the eminent library service that brings whatever ze orders from the anonymous librarian all the way to hir desk within a day or two. The yellowed pages are full of pencil underlining and notes, and ze finds these reader's comments, made during the dark times, as intriguing as the text itself; the first library stamp is from 1975, the book has been frequently borrowed in the late ' 70 s and early '80s, but only sporadically thereafter. How was it read, ze wonders, during the State of Emergency; as subversive critique or as ideological support of the politics of purity outlined and implemented by Afrikaner academics, all affiliated with Stellenbosch University. This was arguably the ideological cradle of apartheid (although two of the Afrikaner fellows protest vehemently against hir allegation, 
made in passing over lunch, and stress that the racial segregation was long established as an integral part of the British colonial indirect rule; group area laws were implemented already in 1913 , after the formation of the union, long before the Nationalist Party's takeover in '48).

Ze imagines the author of these notes as one and the same Afrikaner student, who has struggled with the English, dictionary in hand, and had to look up and translate consecrated (heilige) and profane (goddelose/heidense). Written in 1966, in High Modernity, in the heyday of Western rationality and TechnologyOptimism, Purity and Danger is a radical cultural self-examination-“...[W]e shall not expect to understand other people's ideas of contagion, sacred or secular, until we have confronted our own" (Douglas 1966: 28)-which portends the civilisation critique and the postmodern breakup of the '70s and '80s. High Modernity coincides with High Apartheid-a yearly growth rate of six to seven per cent, dislocations, evictions, expulsions, obscene exploitation, the negation of modernity, reversing the influx from country to city, returning unwanted labour units to the miserable reservoirs called homelands (later Bantustans), while the white citizens prosper in unprecedented wealth (Dubow 2014: 99-101).

Dirt is essentially disorder. Separating, purifying, demarcating and punishing transgressions have as their main function to impose system on an inherently untidy experience. Only by exaggerating differences (within-without, malefemale, black-white) is a semblance of order created (Douglas 1966: 4).

A semblance of difference? False diversity - as the apartheid regime's encouraging of the con festivals in the Cape, letting the coloured show their colours; even the queers come out of the closets to parade at the white masters' back. The queer coloured, that is, subject to the indifferent white gaze in the non-existent public sphere, the non-public non-space of absent contagion.

Why? Simon, one of hir fellows at the Institute, gave hir the book with this intriguing title, by the late sociologist Charles Tilly (2006). Written under the verdict of a terminal cancer, which most certainly added a special clarity to the thought, it is, as the subtitle reads, about "what happens when people give reasons ... and why". Simon was one of the first to analyse the outbursts of deadly violence against "foreigners and strangers" in May and June 2008, a carnage reminiscent of and as abhorrent as the "black-on-black" butchery of the interregnum years. As ze is reading, new vile xenophobic attacks are being carried out, in Soweto and other black holes of the persisting apartheid cityscape, targeting Somali vendors, often in the presence of the 
police, who in some instances even participate in the looting. A month later Durban will explode in murderous rage, instigated by the Zulu king in leopard-skin garment, spreading inwards from the dismal townships to the city centre; ze will watch the footage in awe, the familiar street signs, the city mall, the burning tyres, threatening thugs with pangas and iwisas and kicked-around strangers running for shelter. Yesterday's breaking news of the bullying and harassment of black secondary school children by their white peers and self-appointed superiors will be forgotten. The concerned expert panels assembled on prime time in all the news channels to discuss why race is re-emerging as top obsession of the South African mind twenty years after the demise of apartheid will reconvene to explain the xenophobic logic of inclusion and exclusion.

Why is indeed the most pertinent question. Why do victims become perpetrators? Have the former guest workers in their own country sim-

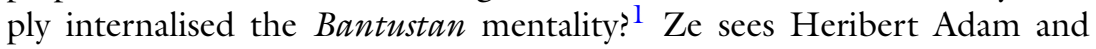
Kogila Moodley for a coffee at the Institute, after just having finished reading their comparative study on "xenophobia, citizenship and identity in South Africa, Canada and Germany". The chillingly premonitory analysis could not have been timelier. Why? Apartheid is only part of the answer, and Neo-liberalism but another partial reason. Xenophobic attitudes are equally strong among elites, black as white, and increasing in all groups, with Indians being slightly more tolerant than others. On the other hand, ecumenical tolerance still prevails; neither Islamism nor Islamophobia are as yet featuring in the public debate. The South African divided society has long learned to co-exist with diversity. That, says Heribert, is the main hope to overcome xenophobia. And yet now, in contrast to 2008, ANC leaders are coming out with coded xenophobic statements, Zuma's own son even breaking the code, in allegiance with the Leopard-skin pillbox king.

Sin is fundamentally conceived as a material impurity. Blood, a holy substance endowed with miraculous power, is expected to remove the stain of sin (Eichrodt 1933). But since the common verb for making atonement can be translated as both "wipe away" and "cover", the meaning may just as well be interpreted as "covering up one's guilt from the eyes of the offended party by means of reparation" (ibid.). 
Covering up one's complicity... Responsibility-in-complicity. Ze orders Mark Sanders' analysis of the intellectual and apartheid; ze was aware of its existence, but never read it before, although ze read Sanders' later book on the TRC. Now Complicities appears as one of the really important analyses of the complexities at the core of the South African transition (a good verdict for a book, to mature with age).

"When opposition takes the form of a demarcation from something, it cannot, it follows, be untouched by that to which it opposes itself. Opposition takes its first steps from a footing of complicity" (Sanders 2002: 9). Therefore, the negotiation of complicity should be an essential moment in intellectual responsibility.

A year later, on hir return to the Western Cape, ze will disclose another correspondence; Jacob Dlamini's Askari, the beautifully disturbing "story of collaboration and betrayal in the anti-apartheid struggle".

How different would the history of apartheid sound, asks Dlamini rhetorically, if told not as the story of racial war but of what we might call a fatal intimacy between black and white South Africans (2014: 2) $)^{2}$ ? It is an intriguing assumption, given that the subject of the interrogation is Glory Sedibe, the defector, traitor, sell-out, turn-coat, collaborator, Comrade September turned apartheid agent $\mathrm{Mr}$ X1, abhorred by both his former fellow freedom fighters in the ANC and his later white trash superiors at Vlakplaas. Complicity is mutual, collaboration always marked by ambiguity ... The ruthless Askari, perpetrator and victim, fell outside the frame of the TRC. Nobody wants to acknowledge that in the apartheid dusk most cats were grey.

The most captivating part of Adam and Moodley's book is the couple's concluding autobiographies; she, an Indian from Durban, granddaughter of indentured labourers, he a German war child, a catholic conservative turned radical rebel of the Frankfurt Institute for Social Research, their fates unite in Durban during high apartheid, transgressors of the Immorality act forced in exile for loving across the race barrier; now Canadians, world citizens, intercontinental commuters...

Hir own biography has none of the cosmopolitan ingredients. Ze was privileged middle-class, though growing up in one of Malmö’s “Million programme" inner suburbs, and naturally assumed an attitude of superiority and alienation. Only after moving to Stockholm, to become a journalist, 
did ze start to identify with Malmö, and precisely for the "cosmopolitanism" ze had hardly experienced hirself. The Yugoslav immigrants, ze remembers, were commonly patronised. Southern Europeans in general were looked down upon. In retrospect it is hard to understand where this inherent prejudice came from. Hir family was liberal, open-minded. Culturally homogeneous Sweden of the 1960s was programmatically modern and affirmatively anti-racist (avant la lettre), with its prominent jazz scene and mixed marriages. The Swedish Sin was transgressive, the most defiant degree of Immorality. Ze received Stokely Carmichael's Black Power as a guerdon in 7 th grade, while never even reflecting on hir own assumed sense of privilege and superiority. Ze recalls with shame the bullying of the few Jews, not for being Jews, but because they were strange, non-conformant, yet trying hard to appease, bearing the humiliation with resignation, and how ze never interfered in their defence but rather added to the insults. This is as shameful as hir blatantly racist declarations after the first (tough) encounters with the US reality on hir adolescent great tour of the Americas. In the course of the journey's first three days, ze was robbed twice, at the YMCA in New York and the Greyhound bus station in San Francisco, and then next to raped by a Vietnam veteran who helped hir report the second robbery and offered hir his place to stay, only to demand that ze give him a handjob, and barely letting hir get away with that.

At lunch the next day, Ulrike from Austria, who was surprised that Swedes would go to Turkey - and even Iran!-for transplantations, and who, when confronted, admitted her prejudice, says that the interesting thing about studying apartheid at its roots is that it forces you to confront the racist in yourself.

When ze comes upon the central passage on Dirt as matter out of place, ze finds to hir surprise that there are neither notes nor underlining in four pages. Has the reader jumped them, or skimmed them so extensively that the reading literally has left no marks? Ze thinks of the scribbled notes as reflections of the words' imprint on the reader's mind; reading as a physical, bodily, sensual practice, the tangible text tattooed over yellowish pages of living skin.

Where there is dirt there is system. Dirt is the by-product of a systematic ordering and classification of matter, in so far as ordering involves rejecting inappropriate elements. Hence, "our pollution behaviour is the reaction which 
condemns any object or idea likely to confuse or contradict cherished classifications" (Douglas 1966: 35).

In South Africa, by contrast to India, it's not the clash between dogmatic conflicting identities, but the very opposite: insecure, fragile identities searching to assert themselves, develop self-esteem, escape humiliation and reverse denigration (Adam and Moodley 2013: 193). Hence, it's rather a lack of identity that instigates murder. Xenophobic violence as identity assertion reverses daily humiliation. Reverses and relieves. Perpetration is apparently joyful, as noted by Simon (funny that ze come across his quote just after eating lunch with him); the emotional dimension of xenophobia symbolically frees the perpetrators from the real deprivation (Bekker 2010: 137).

The re-appearance of necklacing; the powerless community assuming power by deciding over life and death in a gruesome ritual. Punishment by burning tyre. The stabbing of Emmanuel Sithole in Alexandra in front of the camera captures the moment of murderous impulse, whereas the necklacing of Angolan shebeen owner Joseph Hipandulwa in Kayelitsha is unbearable to even imagine (Adam and Moodley, 195). Like the beheading by knife of IS prisoners. Is the gruesomeness the perversion of this humiliation in reverse? Cleansing by fire, by fear, by fury-targeting the vulnerable, powerless makwerekwere, while the real culprits for the misery of the murderers are immune from their rage, since they have the power to retaliate. Julius Malema's young supporters put tire necklaces on statues commemorating World War I ... (Hans-Dieter, the new German fellow warns that the removal of Cecil Rhodes from the UCT campus will be the beginning of a Culture War: Soon they'll start burning books that remind of colonial times).

The Institute is a refuge. Nobody disturbs hir; the only requirement is to be there, in situ, to participate in the lavish lunches, Monday to Friday, and the afternoon seminar every week, when the researchers present their findings to each other. After seminars there is always wine and snacks, generous yet moderate; what remains in the bottles is left to self-service when tables are cleaned, but nobody would dream of overdoing the welcome, let alone go somewhere else to continue the party. Some even go back to their offices after the seminars. Michael, the composer, artist in residence since more than half a year, virtually lives in his room on the ground floor, with an electric piano and a mattress, on which he naps after lunch, and the note blades of his work in progress papering the walls. But he is receding to 
Cape Town over the weekends, where his wife is soon going to meet up from their second home in London.

Elmi, a surgeon from Cape Town, commutes from home and is sometimes late or not appearing at all, because she has been summoned to her clinic. "I had to do a kidney", she excuses herself with a smile, and looks as if she had just come from an invigorating session of Pilates at the nearby gym. She works on a project on the global organ trade and transplantation industry and speaks, in her seminar, about the difficulties in matching organ donors and recipients when the genetic variation is as vast as it is in South Africa (ze pricked up hir ears: did ze get that right? Is genetic variation a euphemism for racial differences? Does mixing augment or diminish the genetic variation? Are there strictly medical arguments to support creolisation and contamination?) Ze knocked on Elmi's door for an answer, but she couldn't give hir a straight one. In the long run, yes, but in a short perspective there is vulnerability. In the long run we are all coloured. But in the short run we are all dead. Vanitas vanitatum omnia vanitas.

The fear of blood mixing haunts not only the Boer, but all white settlers;

in an abyssal historical irony, given the origins of the tongue in which Afrikaner nationalists ground their identity, it shuns hybridity and measures purity. (Sanders 2002: 82)

Not only the hybrid is abominated, but everything that breaks the classifications, stated by the merciless God. An English-speaking black is the most frightening abomination. Even the opponents of apartheid (avant la lettre) opt for racist solutions. Olive Schreiner, writer and feminist pioneer, and explicit opponent to Cecil Rhodes' colonial savagery, talks of South Africa as "a mixture of races", but only in a social sense, since she, like everyone else, opposes miscegenation; her vision of a federation of South African states, as opposed to the Union of 1910 , is a vision of a racially separated society that clearly resembles the radical apartheid visions of ethnic nations in separate development (ibid.).

The crux is of course simply that the whites are a minority, and in a state where all citizens were given equal opportunities, they would be a powerless minority. In a state of unchecked miscegenation, they would be "ploughed under" by the black masses, tarnished, vanished ... tainted by the tar brush. 
God's stepchildren ... Coetzee points to the direct parallel to the Christian ideas of 'falling from grace' and 'original sin' (1988: 141). Shame is not strong enough to denote the original mixing of fluids because black blood is a form of defilement; a formless horror evading description - much like the HIV virus, which can be kept at bay, at best, but never cured. The only way the polluted community can cleanse itself is by expelling the polluter. And the only way that the responsible polluter can put an end to the suffering is by sexual abstinence, thereby killing the taint (virus) and extinguishing the bloodline that carries it - the ever-damned tradition of hybrid impurity.

For the architects of apartheid, apart-ness means the self-determination of every nation, and the principle that no nation be dominant over another. Those who take this notion seriously propose Total Separation. Werner Eiselen, the founder of Volkekunde, never described African cultures as explicitly inferior to "white" culture, but regarded them as being in a state of decline, due to the corrupting contact with "white" society. Subsequently, they ought to be protected from foreign (white, modern) influence and given the chance to develop in line with their own particular cultural imperatives. The favoured metaphor to illustrate that each culture contained its own dynamic for development was Hans Christian Andersen's fairy tale about the ugly duckling that is able to flourish only when it finds itself among its own kind (Eiselen 1948).

Eiselen (1920) conjures the image of Bantu barbarians at the gate, ironically alluding to the white paranoia provoked by "black-peril" propaganda. But, instead of enhancing the advancement of black intellectuals, his conclusion is that they should be saved from the inevitable disappointment of realising that, however hard they tried, they would never be accepted members of the white society, due to racial prejudice. The mission-educated blacks (the abominable English-speaking blacks, mimicking English gentlemen) were doomed to be an "intellectual proletariat" (ibid.). ${ }^{3}$

The only proponent of mixing is Breyten Breytenbach, who launches the idea of Zuid-Afrikanerdom as opposed to the nationalist purism of Afrikanerdom, and defines it as a culture of hybridity (basterskap).

We are a bastard people with a bastard language. Our nature is one of bastardy. It is good and beautiful thus. We should be compost, decomposing to be able to combine again in other forms. Only, we have walked into the trap of the bastard who has acquired power. [...] And like all bastards - uncertain of their identity - we began to adhere to the concept of purity. That is apartheid. Apartheid is the law of the bastard. (Breytenbach 1982: 156) 
Note the ambiguous value in the word bastard... Bastervolk, bastertaal, basterskap are positive notions, on which a new inclusive identity can be built-but the baster is a bastard in the conventional sense that the word has attained. And when Breytenbach returns to Paradise a decade later, at the beginning of the transition, it's only the latter meaning that remains:

The Afrikaners aren't such reprehensible bastards after all. If you leave them to their own devices, they don't really bother other people. The problem is that their minds were warped by European exclusivism. At least they have a modicum of respect for nature and for animals. (Breytenbach 1993: 80)

Elmi's husband, Stephanus, is a musicologist, and also a friend of Michael and Aryan. Ze meets the three of them at the screening of Aryan's latest film, Threnody for the Victims of Marikana, at the University of the Western Cape. The threnody for the striking mineworkers of Marikana in the Gauteng, who were massacred by the police on 16 August 2012, is a shortened version of the film Night Is Coming, Aryan's contribution, as one of three invited artists, to an academic collaboration between the universities of Stellenbosch, Oxford and Harvard on Music and Landscape. The film was supposed to be screened at Harvard, at the third seminar/workshop, but it wasn't because it was thought to have misrepresented what happened in Stellenbosch. (Not what the prominent participants had expected, after flying in, having a good time at the restaurants and wineries and club floors, and flying back to the USK with the contention that the New South Africa has come a long way, as Aryan put it, or as ze reads his scorn.) The threnody leaves nobody unmoved. What does it mean to look at the footage of the massacre through the eyes of the killers? Not the bragging perpetrators, as in Joshua Oppenheim's The Act of Killing, but yet the ones who pull the trigger, the police, the state of decision, life or death, the police state; we are looking over the shoulder of the executioners of a ritual murder, in a state of police, we are witnessing and partaking, complicit in the decomposition, seeing through listening, hearing through watching, the percussive reality of South Africa. Marikana is disturbingly absent in the public memory, a void in the story of the post-apartheid, post-transition nation in the making, the dissonance of an unimaginable Sharpeville in democracy, a Soweto uprising, a state of emergency, a red alert, again, rewinded memories erased; the violent democracy, the virulent police state. And the presence of this 
absence, the melancholy of the threnody ... Aryan, urged to comment, sits down among the audience and lets the images speak, that's how he works as an artist, the provocateur, l'enfant terrible, but never as an empty gesture, always with a purpose, a bit like Jean Rouch and Edgar Morin in Chronique d'un été (1960), turning the tables, calling the viewer ... The productivity of inadequacy (ze can't quite remember the meaning of that note; oh yes, it had to do with Harvard's refusal to screen Aryan's film, with the consequence that it travelled far beyond usual academic circles). His inadequate report of an academic encounter, a conference proceeding contaminated with the brutal footage of the police state. Yes, a perfect example of contamination in the sense that ze is striving at in hir yet to outline project.

How can we live with the presence of the absence? What do we do with the knowledge? "Who is the main actor?" asks one in the audience, a student in his late twenties, scared, as he puts it, by the suggested continuity from the apartheid state. "Who is the responsible?" "You are", says Aryan. "What are you going to do now?"

The troubling thing about Marikana is that it doesn't go away. It is not an event with a beginning and an end, it is still there, in its present absence or absent presence... we are watching it as it unfolds over the shoulder of the police, complicit in the act, in our own inaction, unable to think rationally, adequately.

Somebody asks what Musicology and Stellenbosch are getting out of it, and Stephanus rightly comments that Aryan would not have been able to do the film about Marikana without them. He needs that kind of structure. Aryan does not object. It's a brilliant example of miscegenation of art and academia, an exemplary illustration of what art and academia can accomplish-in disjuncture.

Pollution is like an inverted form of humour, it does not amuse, but the structure of its symbolism uses comparison and double meaning like the structure of a joke (Douglas 1966: 122). The symbolism of the body's boundaries is used in this kind of unfunny wit to express danger to community boundaries. The Coorgs in Karnataka were so obsessed by fear of dangerous impurities entering their system that they treated the body as if it were a beleaguered town, every ingress and exit guarded for spies and traitors. Anything issuing from the body is never to be re-admitted, but strictly avoided (123). The sociological counterpart of this 
anxiety is a care to protect the political and cultural unity of a minority group (124).

Again, it's hir own underlining - or, rather, hir exact transcription, supplemented with "Appadurai" and an expression mark. Ze makes the note to check whether A. refers to D. He must! But you can never be sure. The forking paths often run in parallel, without crossing. In their analysis of xenophobia, Adam and Moodely referred to Freud's narcissism of small differences (1961), but not to Appadurai's Fear of Small Numbers (2006), let alone Purity and Danger, which latter they of course most probably were aware of, as cultivated intellectuals, but not regarded as a relevant reference. Discipline borders are just as carefully policed as genre borders; no, not even necessarily policed, there is simply no cross-going traffic.

Anne Phillips, with whom ze invites Antjie Krog for lunch at the Institute, says she admires hir courage to write about South Africa. She has herself decided not to, after realising the complexities. Antjie also questions hir project in an indirect way. Writing across borders, she says, presupposes that you are confident within your borders, inferring that the vast majority of South Africans aren't; all those who are not writing in English for a white audience (and a white publisher). Ze objects and argues against the seemingly essentialist position; the same that ze criticised in hir reading of Begging to Be Black (2009), the somehow discouraging conclusion of the Transition trilogy, that it is impossible to imagine the other as yourself. For a moment the lunch talk is turning uncomfortable and ze wonders why ze envisioned collaborating with Antjie in hir research proposal. But then afterwards, in hir office, she gives some valuable suggestions, as if their collaboration were already a fact and the farewell is on a friendly collegial note. (The day after ze receives a mail from her, saying: $i$ think why we do not see eye to eye is because both of us are trying to address the intolerance we see in our respective societies, but your intolerance is a first world one and mine a third world one and behove different strategies.)

Envy and narcissism. Envy turned on outsiders. The former victims turned perpetrators single out target groups for their apparently superior abilities. Violence becomes a desperate but decisive method of last resort with which perpetrators compensate for their own shortcomings (Du Toit and Kotze 2011). The real 
culprits - the indigenous elite in cahoots with the old ruling-class-cannot be targeted, since they still wallow in the glory of liberation and effectively silence dissent. The government's lip-service condemnation of xenophobia conceals the fact "that ours is a neo-apartheid state managed by yesterday's anti-apartheid revolutionaries" (Mngxitama 2009).

The threat of the "nearly-we" who imperil our self-concept. "The ugliest manifestations of racism are reserved for immigrants who look, act and talk like us. The more they try to emulate and imitate us, the harder they attempt to belong, the more ferocious our rejection of them" (Vaknin 2011). Germany's extermination of the Jews is the historical proof of this logic (and a forceful argument against assimilation, as proposed by anti-migrant nationalists). But why does minimal difference trigger hostility? Adam and Moodley quote Indian psychoanalyst Sudhir Kakar (1996: 189):

The community in which we are socialised is part of our personal identity. And the clash between internalisation of social rules, i.e. culture, and a person's natural drives is solved through the projection of "bad" representations onto others; first inanimate objects and animals and later people and other groups.

The disavowed bad representations need such "reservoirs"-Muslims for Hindus, Arabs for Jews and vice versa-which also serve as convenient repositories for rages for which no clear-cut addressee is available (Volkan 2006).

Is it really reversible? Some groups are obviously more prone to become reservoirs of bad representations; currently Muslims and Gypsies, previously Jews, Kaffirs, Coolies, Boers... Aryans vs. Jews is not reversible, nor Americans vs. Mexicans. Not even Hindus vs. Muslims, even if that would be closest to an equal and reversible demonization. (There is an interesting passage in David Malouf's novel The Great World (1990), centred on the Australian World War II experience, when the Australian POWs realize that they, in the eyes of the Japanese, are no better than coolies; that the Japanese in fact wish to turn them into coolies - a fate that they, in their self-assured confidence of white superiority, regard as unfathomable, as the horror of horrors.)

Pollution rules, in contrast to moral rules, are unequivocal. They do not depend on intention or a nice balancing of rights and duties. The only material question is whether a forbidden act has taken place or not (Douglas 1966: 130). Physical crossing of the social barrier is treated as a dangerous pollution. The polluter becomes a doubly wicked object of reprobation, first because he crossed the line and second because he endangered others (139). 
When attacked from the outside, solidarity within is fostered. When attacked from within by wanton individuals, these can be punished, and the structure publicly reaffirmed. But the structure can also be self-defeating. Perhaps all social systems are built on contradiction, in some sense at war with themselves (140).

Again, a lucid, revolutionary thought, against the grain of her time, defying both socialist and liberal utopianism; not the end of history, nor the realisation of classless communism, but the perpetual paradox of dual impossibilities: neither growth nor degrowth, neither black nor white.

Ze tries to imagine the mental regimentation and self-deception of an entire community, the complacency of complicity, maybe as banal as the evil of indifference. Or ignorance. The benevolent police state. The very building for the Arts and Social Sciences, where Volkekunde was taught until 2002 , disturbs the harmonious picture with its blatant brutality. The concrete colossus, previously named after Verwoerd's successor, B. J. Vorster, was constructed on the rubble of the evicted "coloured area", Die Vlake, overlooking the new white neighbourhood on the other side of Merriman Avenue, anonymous one-storey buildings, chain-houses, villas, a huge gas station, parking lots; no traces, not even a plaque of remembrance of this Stellenbosch's own District Six. The former Lückhoff Skool, which was also given or traded to the expanding university, is now a centre for community interaction, dutifully telling its story in non-committal half-truths, like the grand display of the university's history, decade by decade, in the University Museum. It would take hir many weeks to find out, but that was where ze ended up in hir first disorientation, a lively square in what had once been Die Vlake, now, again, a fringe area, where the white city ends, a Somali coffee shop and a coloured hairdresser, where ze drops in for a haircut and asks for the direction to Dorp Street, the only street name ze recalls; two months later ze will accidentally rediscover the hairdresser, who will smilingly recall hir and repeat the haircut, and suddenly the pieces of the inner and outer map fall together, and the contours of this other parallel city appear in a flash of illumination, like the stroboscopic lights of the Springbok Pub, less than a stone throw away in the corner of Andringa and Merriman. It all makes sense. 
Dirt is (only) dangerous as long as some identity clings to it. When identity is lost (pulverised, rotted, dissolved) it enters the mass of common rubbish. It is unpleasant to poke about in the refuse to try to recover anything, for this revives identity (160). So long as identity is absent, rubbish is harmless and does not even create ambiguous perceptions. Even the bones of buried kings rouse little awe and the thought that the air is full of the dust of corpses of bygone races has no power to move. Where there is no differentiation there is no defilement.

The quest for purity is pursued by rejection. It follows that when purity is not a symbol but something lived, it must be poor and barren. It is part of our condition that the purity for which we strive and sacrifice so much turns out to be hard and dead as a stone when we get it. ["Purity" and "rejection" are here not only underlined but encircled by the anonymous Afrikaner student, as is the following entire sentence:]

Purity is the enemy of change, of ambiguity and compromise.

What is, then, the attraction of the barren, of that which is hard and dead as stone? Sartre (1948) portrays the anti-semite as someone who wants to adopt a mode of life in which reasoning and the quest for truth plays only a subordinate part, in which nothing is sought except what has already been found, in which one never becomes anything but what one already was.

But is it a choice to reason falsely? Purity cannot be consciously conceived as un-true. Yet anything that questions the assumed truthfulness and threatens the order will be condemned as pollution - or contamination.

Douglas, more radical in thought than Sartre, critiques the implicit division between "our thinking" and the rigid black and white reasoning of the anti-semite. Because, she writes [and this is doubly underlined and encircled] the yearning for rigidity is in us all (162). The little perpetrator. Sanders expounds on a self-critical remark in the TRC report, on its failure to focus sufficiently on the dimension of "moral responsibility", stating that the attention on the deeds of the exceptional perpetrator led to "fail[ure] to recognise the 'little perpetrator' in each of us" (Sanders 2002: 3); whereas Breytenbach adds the insight that, as an intellectual, it is not enough to resist the system in its overt manifestations, but it is necessary to find the roots of the conversion of foldedness with the other into forms of complicity in its denial (ibid.: 157). This is what makes apartheid exemplary for the intellectual as a figure of responsibility-in-complicity. It is necessary to have not only an ideal of freedom or autonomy but an account of 
sufficient power to capture how that ideal is, at a fundamental level, susceptible to perversion as something like apartheid (ibid.: 190).

The lasting insight of Black Consciousness was that apartheid was not, in any essential sense, an achievement of separateness at all, but it was a system of enforced separation that, paradoxically, generated an unwanted intimacy with an oppressive other [unwanted, or ambiguously desired?]. In a narrow sense, it decreed apartness; in a general sense, it disavowed relation (foldedness in human being with the other). "If such a disavowal of relation is what tends toward support for apartheid, it is an acknowledgement of this complicity and its disavowal at the heart of apartheid that is the essential starting point of any opposition to apartheid".

Already on hir first Saturday night in Stellenbosch, Aryan suggested that ze go to "try hir moves" at the Springbok Pub. Ze was tired and hesitant; if it weren't for the expectation to see Aryan there, ze would not have gone, thinking that it would be a posh or hip show-off venue for the beautiful people (why did ze expect that?). It was the opposite. Ze had a couple of Black Label (Black Labour, White Guilt) in the sports bar, to dare approach the dance floor in the other room, irresistibly drawn by the drums and base and the videos projected on the wall, assuming to be viewed as a sexagenarian voyeur, a freak, the only white among coloureds, certainly the eldest on the floor. But the atmosphere is one of familiarity, the women in their thirties or forties, with their friends or their husbands, curiously observing hir and inviting hir to dance with them, embedding hir in unpretentious hospitality, and ze is overwhelmed by their welcoming warmth. The sound of the Cape, the progenies of this crossroads, the breed of three hundred years of intimacy, wanted or unwanted, defying the boundaries of slave and master, white and black; the bruin-mense as the Afrikaners called them, in affection and contempt, less than white but better than black, privileged among the unprivileged, yet despised for being half-caste, for being neithernor, without tribe- the left-overs of humankind, as Madame De Klerk so lovingly called them. Bastards, like the Afrikaners, but of a darker shade; the fine divisive line could cut a family in two, siblings ending on each side of the insurmountable border. Humble bastards, inconsolably compromised by their not-quite-white-ness. On hir second visit to the Springbok Pub, 
ze arrives at the end of a birthday party; now ze's recognised, prompted to eat and drink, and one of the pitiful husbands teaches hir to dance properly ... Syncopating surprisingly to-ze searches in vain for the proper metaphor-Saturday night insouciance.

After finishing reading ze still has problems to grapple the ambiguity. Dame Douglas to-be outlines a possible dichotomy between dirt-affirming and dirt-rejecting philosophies. Whereas the latter are typically incomplete but optimistic, the former tend to be more complete (complex) and also pessimistic. Yet, although fascinated by transgressions, she remains herself essentially a conservative friend of order.

\section{Notes}

1. D. Everatt in special issue of the journal Politikon, 2011, in Adam and Moodley (2013: 37).

2. The notion of "fatal intimacy" is borrowed from Njabulo Ndebele.

3. The term "intellectual proletariat" was borrowed from historian Arnold Toynbee.

\section{REFERENCES}

Adam, H. and K. Moodley. 2013. Imagined Liberation: Xenophobia, Citizenship and Identity in South Africa, Germany and Canada. Stellenbosch: SUN Press. Appadurai, A. 2006. Fear of Small Numbers: An Essay on the Geography of Anger. Durham: Duke University Press.

Bekker, S. 2010. "Explaining Violence Against Foreigners and Strangers in Urban South Africa: Outbursts During May and June 2008." The African Yearbook of International Law 16, 125-149.

Breytenbach, B. 1982. A Season in Paradise. New York: Persea Books.

Breytenbach, B. 1993. Return to Paradise. London: Faber and Faber.

Coetzee, J. M. 1988. White Writing: On the Culture of Letters in South Africa. New Haven and London: Yale University Press.

Dlamini, J. 2014. Askari: A Story of Collaboration and Betrayal in the AntiApartheid Struggle. Johannesburg: Jacana.

Douglas, M. 1966. Purity and Danger: An Analysis of Concepts of Pollution and Taboo. London: Routledge \& Kegan Paul.

Dubow, S. 2014. Apartheid 1948-1994. Oxford: Oxford University Press. 
Du Toit, P. and H. Kotze. 2011. Liberal Democracy and Peace in South Africa. Johannesburg: Palgrave Macmillan.

Eichrodt, W. 1933. Theologie des Alten Testaments. Leipzig: Hinrich.

Eiselen, W. W. M. 1920. "Die Naturellevraagstuk: 'n Lesing gchou op 7 Mei 1920 voor die Filosofiese Vereniging van die Universiteit van Stellenbosch".

Eiselen, W. W. M. 1948. “Die Bevolkingsvraagstuk van Suid-Afrika, Sosiologies Beskou met Besondere Aandag aan die Arbeidsgemeenskap van Blankes en Naturelle en die Implikasies van Apartheid," 'n referaat gelewer op die Simposium van i Julie, 1948, van die Jaarvergadering van die Akademie vir Wetenskap en Kuns te Orange Free State.

Freud, S. 1961. Civilization and Its Discontents. 1st American ed. New York: W. W. Norton.

Kaganof, A. 2014. Night Is Coming: Threnody for the Victims of Marikana. Cape Town.

Kakar, S. 1996. The Colors of Violence. Chicago: The University of Chicago Press. Krog, A. 2009. Begging to Be Black. Cape Town: Random House Struik.

Kross, C. 2002. "W. W. M. Eiselen: Architect of Apartheid Education." In The History of Education Under Apartheid, 1948-1994: The Doors of Learning and Culture Shall Be Opened, edited by P. Kallaway. New York: Peter Lang.

Malouf, D. 1990. The Great World. London: Chatto \& Windus.

Mngxitama, A. 2009. "We Are Not All Like That: Race, Class and Nation After Apartheid." In Go Home or Die Here: Xenophobia and the Reinvention of Difference in South Africa, edited by S. Hassim, T. Kupe, and E. Worby, 189-208. Johannesburg: Wits University Press.

Sanders, M. 2002. Complicities: The Intellectual and Apartheid. Durham, NC: Duke University Press.

Sartre, J.-P. 1948. Anti-Semite and Jew [Réflexions sur la question juive]. New York: Schocken Books.

South Africa, Truth and Reconciliation Commission. 1999. TRC Report. Vols. 1-5. London: Macmillan.

Tilly, C. 2006. Why? [What Happens When People Give Reasons... and Why]. Princeton, NJ: Princeton University Press.

Vaknin, S. 2011. Malignant Self-Love: Narcissism Revisited. Prague: Narcissism Publishers.

Volkan, V. 2006. Killing in the Name of Identity. New York: Ingram. 
Open Access This chapter is licensed under the terms of the Creative Commons Attribution 4.0 International License (http://creativecommons.org/licenses/by/ $4.0 /$ ), which permits use, sharing, adaptation, distribution and reproduction in any medium or format, as long as you give appropriate credit to the original author(s) and the source, provide a link to the Creative Commons license and indicate if changes were made.

The images or other third party material in this chapter are included in the chapter's Creative Commons license, unless indicated otherwise in a credit line to the material. If material is not included in the chapter's Creative Commons license and your intended use is not permitted by statutory regulation or exceeds the permitted use, you will need to obtain permission directly from the copyright holder.

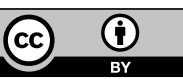

